\title{
EMG frequency spectral characteristics of inspiratory accessory muscles during the shoulder lifting motion in throwing athletes
}

\author{
Características espectrais de frequência EMG da musculatura acessória \\ inspiratória durante o movimento de elevação do ombro em atletas \\ arremessadores
}

\author{
Charlini Simoni Hartz'1 Paulo Fernandes Pires', Marlene Aparecida Moreno', Delaine Rodrigues Bigaton¹
}

\begin{abstract}
Background: Dysfunctions related to the shoulder joint are very common in throwing athletes, due to the overhead generated in repetitive movements with your arms above your head. In addition, in handball, the movements are of high intensity, which generates a large metabolic demand and high ventilatory demands. Studies show that highest work of the respiratory muscles, coupled with high mechanical requirement in the upper limbs, generates a dual requirement under the inspiratory muscles in these athletes, leading to limitations related to muscle fatigue. Objective: The objective of this study was to evaluate the EMG frequency spectral characteristics (fatigue index) to accessory muscles of inspiration, through the induction of shoulder elevation movement in handball athletes. Method/Design: The sample consisted of 25 male athletes with an average age of 20 years. Fatigue index was measured by surface electromyography (mean and median frequency - $\mathrm{Hz}$ ), in which the volunteers performed isometric movement of elevation of the shoulders, and after collection, the data were processed off-line on Matlab R2014a software. For statistical analysis used the Shapiro-Wilk test to test the normality of the data, followed by the comparison of data through the Student $t$ test for independent samples. Significant difference was considered for $p$ value $<0.05$. Results: The results showed a significant difference between the mean and median frequency values for the sternocleidomastoid muscle right compared to the left sternocleidomastoid muscle. Conclusions: We conclude that during isometric movement of shoulder elevation, there was asymmetry in the frequency spectral characteristics of only one accessory muscles of inspiration, presenting asymmetry, and greater fatigue in the sternocleidomastoid muscle dominant side in relation to the non-dominant side.
\end{abstract}

Keywords: Handball; Muscular fatigue; Electromyography.

\section{RESUMO}

Introdução: As disfunções relacionadas à articulação do ombro são muito comuns em atletas arremessadores, devido à sobrecarga gerada nos movimentos repetitivos com os braços acima da cabeça. Além disso, na modalidade do handebol, as movimentações são de alta intensidade, o que gera uma grande demanda metabólica e altas demandas ventilatórias. Estudos apontam que o trabalho elevado da musculatura respiratória, somado a alta exigência mecânica nos membros superiores, gera uma dupla exigência sob a musculatura inspiratória nestes atletas, podendo levar a limitações relacionadas a fadiga muscular. Objetivo: O objetivo deste estudo foi avaliar as características espectrais de frequência EMG (índice de fadiga) de músculos acessórios da inspiração, por meio da indução do movimento de elevação do ombro em atletas de handebol. Método: A amostra foi composta por 25 atletas do gênero masculino, com idade média de 20 anos. O índice de fadiga foi obtida por meio da eletromiografia de superfície (frequência média e mediana - Hz), no qual os voluntários realizaram o movimento isométrico de elevação dos ombros, e após coleta, os sinais foram processados off-line no software Matlab ${ }^{\circledR}$ R2014a. Para a análise estatística utilizou o teste Shapiro-Wilk para testar a normalidade dos dados, seguido da comparação dos dados por meio do teste $t$ de student para amostras independentes. Para diferença significativa foi considerado o valor de $\mathrm{p}<0.05$. Resultados: Os resultados apresentaram diferença significativa entre os valores de frequência média e mediana, para o músculo esternocleidomastóideo direito em relação ao músculo esternocleidomastóideo esquerdo. Conclusão: Concluímos que durante o movimento isométrico de elevação do ombro, houve assimetria nas características espectrais de frequência de apenas um dos músculos acessórios da inspiração, portanto apresentando assimetria e maior fadiga no músculo esternocleidomastóideo do lado dominante de arremesso em relação ao lado não dominante.

Palavras-chave: Handebol; Fadiga muscular; Eletromiografia.

Corresponding Author: Charlini Simoni Hartz. José Miguel Sotto, 52 - Terra Nova, Piracicaba (SP), Brazil. Zip Code: 13.423-712, E-mail: charlinih@hotmail.com ${ }^{1}$ Physical Therapy post-graduation program, Universidade Metodista de Piracicaba (PPGF-UNIMEP), Piracicaba (SP), Brazil.

Financial support: None.

Submission date 4 February 2015; Acceptance date 6 May 2015; Online publication date 11 May 2015 


\section{INTRODUCTION}

In athletes who perform throwing motion in sports such as handball, tennis, baseball, and volleyball, the appearance of disorders related to shoulder joint is very common, and are usually related to high performing repetitively movements with his arms up the head, causing biomechanical overload on this joint, as well as on all muscle groups involved in the movement of pitch. ${ }^{(1-3)}$

The handball mode, specifically, requires a large mechanical requirement in the upper limbs during the match, due to the high stress during moments of physical contact body and the high number of shots made. ${ }^{(4)}$ In addition, this mode has drives features high intensity requiring high ventilatory demands, which generates a large metabolic demand to these athletes, ${ }^{(5)}$ which may lead to limitations related to respiratory muscle fatigue and reduced physical performance. ${ }^{(6)}$

Recent studies have pointed out that in sports that feature high-intensity characteristics, the work of the respiratory muscles is very high, and when it is associated with high mechanical requirement, which is related to modalities that require a lot of activity in the upper limbs, occurs two requirements under the inspiratory muscles during the time of departure. ${ }^{(7)}$

Lomax et al. ${ }^{(8)}$ reported that in general, the inspiratory muscles, including the diaphragm, external intercostal, anterior scalene, sternocleidomastoid, pectoralis major and upper trapezius, ${ }^{(9)}$ may be susceptible to fatigue during maximal and submaximal sports activities. The muscle fatigue process is usually defined as a point at which a particular level of strength can not be maintained. ${ }^{(10)}$

Surface electromyography (EMG) has been used especially to evaluate the muscle fatigue index in musculoskeletal conditions, by analyzing the power spectral density (PSD) of the EMG signal. Thus, to analyze the EMG signal into its frequency components, it is necessary to calculate the the mean and/or median of the PSD (EMG frequency spectral characteristics) despite the median frequency values are most commonly used because they are less sensitive to noise and/or interference. ${ }^{(10)}$

Recent studies have investigated, through the EMG, the fatigue index of upper limb muscles performing dual mechanical function during the sporting gesture, as the pectoralis major muscle, in which muscle fatigue was observed with reduction of EMG median frequency after maximum activities sports. ${ }^{(11-14)}$

However, we found no studies that verify the fatigue of inspiratory muscles compared to the shoulder lifting movement in throwing athletes. One study found the sternocleidomastoid (SCM) muscle behavior against the lifting of the arms, for ergonomic analysis, showing the occurrence of co-activation of this muscle against the motion. ${ }^{(15)}$

Our hypothesis is that the inspiratory accessory muscles in throwing athletes, present muscle fatigue characteristics of the dominant throwing hand, observed by reducing the mean and median EMG frequency and can be presented asymmetrically due to the great burden on the dominant upper limb throwing.

The objective of this study was to evaluate the EMG frequency spectral characteristics (fatigue index) of accessory muscles of inspiration (sternocleidomastoid, upper trapezius and pectoralis major), through the induction of sustained / isometric motion of shoulder elevation in throwing athletes the handball sport.

\section{METHODS}

We evaluated 25 male athletes, handball practitioners, with an average age of 20.8 years $(+4.4)$, average body mass index (BMI) of $25.3(+3.2)$, all with pitch dominance on the right. As inclusion criteria, volunteers should: be athletes in competitive level for at least six months; conduct all training with the team; not make use of medications that could interfere with muscle contraction, such as muscle relaxants; having the absence of any musculoskeletal injury shoulder and neck. The study was approved by the Research Ethics Committee of UNIMEP under Opinion No 62/13.

To perform the surface electromyographic examination was used a purchase module of 8 EMG channels 830 (EMG System of Brazil Ltda ${ }^{\circledR}$ ), analog/digital converter (EMG System of Brazil Ltda $^{\circledR}$ ) with 16-bit resolution, frequency acquisition $2000 \mathrm{~Hz}$. the signal acquisition system was connected to a laptop via USB and a battery capable of \pm 12 volts $(V)$ and 2.2 ampere hour $(\mathrm{AH})$.

The electromyographic signals collected were sampled synchronously and stored for later viewing and processing. For the acquisition and storage of digitized signals data files, we used the software EMG System of Brazil for Windows.

The signals were processed off-line in Matlab ${ }^{\circledR}$ R2014a software, which was used a digital filter type Butterworth 4th order, two poles with high pass $20 \mathrm{~Hz}$ and low pass $500 \mathrm{~Hz}$. The analysis was conducted in the frequency domain to obtain the spectral power values of EMG (mean and median frequency - $\mathrm{Hz}$ ) by fast Fourier transform (FFT) algorithm. It notes that was eliminated the 1st and last second of each signal collected to avoid any interference or noise that could occur in these phases.

To capture the action potential of the upper trapezius (UT), clavicular portion pectoralis major (PM) and SCM muscles, bilaterally simple differential electrodes were used, made up of two pure silver bars of $10 \mathrm{~mm}$ long and $1 \mathrm{~mm}$ wide each positioned in parallel with inter distance $10 \mathrm{~mm}$ electrode. The encapsulation of the electrode had a rectangular shape, made of PVC $(35 \times 20 \times 10 \mathrm{~mm})$. The electrode showed the capsule under a pre-amplifier circuit with a gain of 20 times $( \pm 1 \%), \mathrm{IRMC}>100 \mathrm{~dB}, 10 \mathrm{G} \Omega$ input impedance.

The reference electrode, made of metal with circular shape and conductive gel/adhesive for attachment was placed on the sternal notch volunteers in order to eliminate any outside interference. 
The simple differential electrodes were placed in the wombs of the above muscles, parallel to the muscle fibers of the same and the silver bars perpendicular to them, being fixed by adhesive to the skin previously cleaned with cotton soaked in $70 \%$ alcohol solution, rubbed and shaved with sandpaper when necessary.

Following the recommendations Cram, Kassman and Holtz (1998) 16 to the SCM muscle right (R) and left (E), the electrodes were placed $2 \mathrm{~cm}$ away from the mastoid process, slightly later than the middle of the belly, in parallel with muscle fibers. For the upper trapezius muscle fibers $D$ and $E$, the electrodes were placed at the midpoint of the top margin at a distance of about eight centimeters of the seventh cervical vertebra towards the acromion. For the pectoralis major clavicular portion $D$ and $E$, the electrodes were placed $2 \mathrm{~cm}$ below the clavicle, medial to the axillary fold, at an oblique angle to the collarbone.

Data collection was conducted in an air-conditioned room with controlled temperature maintained at $23 \pm 2^{\circ} \mathrm{C}$, and illuminated with incandescent bulbs.

\section{Procedures}

For electromyographic collection, the volunteers remained seated in an adapted chair, with a fixed upper support for carrying out the elevation of the shoulders. The signal collection took place in elevation isometric condition of the shoulder girdle bilaterally, for 30 seconds contraction. The collection procedure was repeated 3 times with 2-minute rest interval. After collecting the signal was eliminated the 1 st and last second (30) of each signal processing, eliminating any interference or noise that could occur in these phases. It is worth mentioning, which was used for analysis, the average mean and median frequency of the EMG signal (average of 3 repetitions collected).

\section{Statistical analysis}

The analysis was performed via software SPSS 20.0 (SPSS Inc, Chigaco, IL, USA). All data were expressed as mean and standard deviation, as well as the average difference and confidence interval of $95 \%$ between muscle sides. The Shapiro-Wilk test showed normal distribution of data ( $p>0.05)$. For comparison between muscle sides separated by EMG power spectral variables (mean and median frequency) we used the Student t test for independent samples. For significant difference was considered the level of $5 \%$ $(p \leq 0.05)$.

\section{RESULTS}

Table 1 and 2 show the results of the EMG mean frequencyvalues $(\mathrm{Hz})$ and EMG median frequency $(\mathrm{Hz})$, respectively, of the muscles analyzed during the movement isometric elevation of the shoulder girdle. Significant differences were found between the mean frequency values and median frequency, only for the ECM R muscle compared to ECM L muscle and demonstrating that the muscle in question the right, introduced himself significantly more fatigued than the left, during the $28 \mathrm{sec}$ analyzed movement.

Table 1. Overall average $(n=25)$ of the EMG mean frequency $(\mathrm{Hz})$ of the muscles analyzed for 28 sec isometric motion of elevation of the shoulder girdle.

\begin{tabular}{|c|c|c|c|c|}
\hline Muscles & Sides & Mean \pm SD & mean difference (IC 95\%) & $p$ value \\
\hline \multirow[b]{2}{*}{ Sternocleidomastoideus $(\mathrm{Hz})$} & Right & $111.12 \pm 14.02$ & \multirow[b]{2}{*}{$-11.32(-20.12 /-2.53)$} & \multirow[b]{2}{*}{$0.01^{*}$} \\
\hline & Left & $122.44 \pm 16.78$ & & \\
\hline \multirow[b]{2}{*}{ Upper trapezius $(\mathrm{Hz})$} & Right & $100.47 \pm 20.17$ & \multirow{2}{*}{$-8.60(-20.40 / 3.20)$} & \multirow[b]{2}{*}{0.15} \\
\hline & Left & $109.07 \pm 21.31$ & & \\
\hline \multirow{2}{*}{ Pectoral major $(\mathrm{Hz})$} & Right & $94.54 \pm 20.91$ & \multirow{2}{*}{$-1.08(-12.15 / 9.98)$} & \multirow{2}{*}{0.84} \\
\hline & Left & $95.62 \pm 17.90$ & & \\
\hline
\end{tabular}

*Significant difference $(\mathrm{p} \leq 0.05)$. Student $\mathrm{t}$ test. SD: standard deviation; mean difference between muscle sides; $95 \% \mathrm{Cl}$, confidence interval $95 \%$ of the average difference between the muscle side.

Table 2. Overall average $(n=25)$ of the EMG median frequency $(\mathrm{Hz})$ of the muscles analyzed for 28 sec isometric motion of elevation of the shoulder girdle.

\begin{tabular}{|c|c|c|c|c|}
\hline Muscles & Sides & Mean \pm SD & mean difference (IC 95\%) & $p$ value \\
\hline \multirow{2}{*}{ Sternocleidomastoideus $(\mathrm{Hz})$} & Right & $100.52 \pm 16.12$ & \multirow{2}{*}{$-13.07(-23.10 /-3.04)$} & \multirow{2}{*}{$0.01 *$} \\
\hline & Left & $113.59 \pm 19.03$ & & \\
\hline \multirow[b]{2}{*}{ Upper trapezius $(\mathrm{Hz})$} & Right & $90.49 \pm 18.25$ & \multirow[b]{2}{*}{$-8.91(-20.06 / 2.25)$} & \multirow[b]{2}{*}{0.12} \\
\hline & Left & $99.40 \pm 20.90$ & & \\
\hline \multirow{2}{*}{ Pectoral major $(\mathrm{Hz})$} & Right & $82.86 \pm 21.04$ & \multirow{2}{*}{$-1.38(-13.02 / 10.26)$} & \multirow{2}{*}{0.81} \\
\hline & Left & $84.24 \pm 19.87$ & & \\
\hline
\end{tabular}

*Significant difference $(\mathrm{p} \leq 0.05)$. Student $\mathrm{t}$ test. SD: standard deviation; mean difference: mean difference between muscle sides; $95 \% \mathrm{Cl}$ : confidence interval $95 \%$ of the average difference between the muscle side. 


\section{DISCUSSION}

This study investigated the EMG frequency spectral characteristics (fatigue index) inspiratory accessory muscles during sustained/isometric motion of shoulder elevation in handball sport athletes. Our results show a significant difference in the mean and median frequency values between the SCM R and SCM L muscles, during isometric shoulder elevation, which may represent an adaptive response generated by asymmetric overload the SCM muscle, due to the specific gestures executed by throwing athletes.

The results show that the SCM muscle of dominant side pitch of athletes, introduced more fatigued in relation to the non-dominant side pitch, which can be explained by the double mechanical requirement that is generated on this muscles in ways that use large movement in the upper limbs. In rowing athletes during the implementation of the specific rowing gesture, the respiratory muscles is faced with two requirements, it is fundamental and vital role as effector of respiratory control this increase, as well as assists in the generation of propulsive force during the act of paddling. ${ }^{(17)}$

Among the main transactions performed by handball players, the pitches are one of the most senior members, with a run of about 48,000 throwing motion in a season for each athlete. ${ }^{(4)}$ In addition, a study that assessed the main generally drives during the handball match, showed that passes correspond to the movement that occurs more throughout the game by all participating players, regardless of position. ${ }^{(18)}$ Thus, reinforces the confirmation of the high demand and overload that is generated on the complex upper limb dominant in these athletes during the handball match.

Several studies evaluating athletes who performed the pitch activity, observed prevalence of asymmetric responses to the side of dominance and not pitching dominance, pointing out that adaptive changes may occur due to the greater use of the dominant limb and presence of dysfunction and even injuries resulting from these adjustments. ${ }^{(19-21)}$

Not observed in this study significant changes that represented asymmetry to the upper trapezius $R$ and $L$ muscles, during the $28 \mathrm{sec}$ isometric elevation of the shoulder girdle, even though these, engines directly involved in the execution of the throw, acting in aid of the lifting arm, ${ }^{(22)}$ synergistically in the upper rotation of the scapula with the other shoulder muscles and stabilizing the scapula synergistically with the serratus anterior muscle. ${ }^{(23)}$ We should also consider that athletes had specific physical monitoring by coaches, and performed preventive training injuries and balance major muscle groups involved in practice this may have influenced the outcome, once the preventive programs aim to minimize the factors involved in the appearance of lesions. ${ }^{(24,25)}$

We have not found studies in the literature that sought to observe the EMG frequency spectral characteristics (fatigue index) of inspiratory muscles in throwing athletes. Nevertheless, Stirn, ${ }^{(12)}$ Ikuda $^{(13)}$ and Lomax ${ }^{(14)}$ corroborated in part with our findings, since they saw the presence of fatigue through the EMG, the pectoralis major muscle, which carries double mechanical function during sporting gesture of swimmers, generated by high mechanical requirement for the gesture and simultaneous activation in the process of inspiration at high intensities of exercise. However, they did not assess the symmetry of the tested muscles, making it difficult to infer information of asymmetric responses in inspiratory fatigue of athletes evaluated.

Other studies corroborate our findings evaluated the activation of the muscles of the neck workers in the region, and noted that the movements of lifting the arms in this population, for a long time, have generated increased activity of the SCM muscle, increasing the risk of musculoskeletal disorders in this region and can generate high levels of overload and muscle damage, with the possibility of fatigue to the muscles. ${ }^{(15,26-28)}$

This study had limitations as the absence of conducting EMG assessments in the amplitude domain, evaluating and comparing the spectral frequency characteristics with RMS values and integrated EMG signal; and absence of a specific assessment of throwing gesture, even considering the EMG a recommended tool for evaluating isometric movements and not isotonic.

Our results demonstrated the presence of asymmetric fatigue in one of the accessory muscles of inspiration during the lifting motion of the shoulder in throwing athletes. This finding may be an important tool with applicability in sports, and may point disorders related to the respiratory muscles, and support future studies to investigate the behavior of other muscles involved in pitch as well as formulate strategies to minimize the effects of inspiratory fatigue and muscle asymmetry in these athletes through specific training for inspiratory muscles.

\section{CONCLUSION}

We conclude that research hypothesis was partially confirmed, since during the raising movement of the shoulders, was asymmetry in EMG frequency spectral characteristics of only one of the accessory muscles of inspiration evaluated, thereby having asymmetry and increased muscle fatigue in the ECM of dominant side pitch in relation to the non-dominant side in athletes of handball sport.

\section{AUTHORS CONTRIBUTION}

CSH, MAM,DRB concept development (provided idea for the research); CSH,MAM, DRB design (planned the methods to generate the results); MAM supervision (provided oversight, responsible for organization and implementation, writing of the manuscript); CSH, PFP data collection/ processing (responsible for experiments, patient management, organization, or reporting data); $\mathrm{CSH}, \mathrm{PFP}$ analysis/interpretation (responsible for statistical analysis, evaluation, and presentation of the results); $\mathrm{CSH}, \mathrm{PFP}$ literature search (performed the literature search); CSH,PFP writing (responsible for writing a substantive part of the manuscript); CSH,PFP,MAM, DRB critical review (revised manuscript for intellectual content, this does not relate to spelling and grammar checking). 


\section{COMPETING INTERESTS}

The authors declare no conflicts of interest.

\section{REFERENCES}

1. Ejnisman B, Andreoli CV, Carrera EF, Abdalla RJ, Cohen M. Lesões músculoesqueléticas no ombro do atleta: mecanismo de lesão, diagnóstico e retorno à prática esportiva. Rev Bras Ortop. 2001;36(10):389-393.

2. Silva RT. Lesões do membro superior no esporte. Rev Bras Ortop. 2010;45(2):122-31.

3. Seil R, Rupp S, Tempelhof S, Kohn D. Sports injuries in team handball. A one-year prospective study of sixteen men's senior teams of a superior nonprofessional level. Am J Sports Med. 1998;26(5):681-7.

4. Pieper HG. Humeral torsion in the throwing arm of handball players. Am J Sports Med. 1998;26(2):247-53.

5. Povoas SC, Ascensão AA, Magalhães J, Seabra AF, Krustrup P, Soares $\mathrm{JM}$, et al. Physiological demands of elite team handball with special reference to playing position. J Strength Cond Res. 2014;28(2):430-42.

6. Griffiths LA, McConnell AK. The influence of inspiratory and expiratory muscle training upon rowing performance. Eur J Appl Physiol. 2007;99(5):457-66.

7. Steinacker JM, Both M, Whipp BJ. Pulmonary mechanics and entrainment of respiration and stroke rate during rowing. Int J Sports Med. 1993;14(suppl 1):S-15-S-19.

8. Lomax $\mathrm{M}$, Tasker $\mathrm{L}$, Bostanci $\mathrm{O}$. Inspiratory muscle fatigue affects latissimus dorsi but not pectoralis major activity during arms only front crawl sprinting. J Strength Cond Res. 2014;28(8):2262-2269.

9. West JB. Respiratory Physiology The Essentials, USA: Lippincott Williams \& Wilkins, 2012.

10. De Luca CJ: The use of surface electromyography in biomechanics. J Appl Biomech. 1997;13:135-163.

11. Figueiredo P, Rouard A, Vilas-Boas JP, Fernandes RJ. Upper- and lower-limb muscular fatigue during the 200-m front crawl. Appl Physiol Nutr Metab. 2013;38(7): 716-724.

12. Stirn I, Jarm T, Kapus V, Strojnik V. Evaluation of muscle fatigue during 100-m front crawl. Eur J Appl Physiol. 2011;111(1):101-113.

13. Ikuta Y, Matsuda Y, Yamada Y, Kida N, Oda S, Moritani T. Relationship between decreased swimming velocity and muscle activity during 200-m front crawl. Eur J Appl Physiol. 2012;112(9):3417-3429.

14. Lomax M, Tasker L, Bostanci O. An electromyographic evaluation of dual role breathing and upper body muscles in response to front crawl swimming. Scand J Med Sci Sports. 2014.
15. Shin SJ, Yoo WG, Kim TY. Effects of different overhead work conditio non the neck and shoulder muscles. J Phys Ther Sci. 2012;24:197-199.

16. Cram JR, Kasman GS, Holtz J. Introduction to surface electromyography. Gaithersburg, Maryland: Aspen Publishers, 1998.

17. Volianitis S, McConnell AK, Koutedakis Y, McNaughton L, Backx K, Jones DA. Inspiratory muscle training improves rowing performance. Med Sci Sports Exerc. 2001;33(5):803-809.

18. Hespanhol Junior LC, Giroto N, Alencar TN, Lopes AD. Principais gestos esportivos executados por jogadores de handebol. Rev. Bras. Ciênc. Esporte. 2012;34(3):727-739.

19. Oyama S, Myers JB, Wassinger CA, Ricci RD, Lephart SM. Asymmetric Resting Scapular Posture in Healthy Overhead Athletes. J Athl Train. 2008;43(6):565-570.

20. Downar JM, Sauers EL, Mourrtacos SL. Chronic adaptations in the throwing shoulder of professional baseball players. J Athl Train. 2002;37(suppl 2):S-17-S-18

21. Myers JB, Laudner KG, Pasquale MR, Bradley JP, Lephart SM. Scapular position and orientation in throwing athletes. Am J Sports Med. 2005;33(2):263-271.

22. Ahamed NU, Sundaraj K, Ahmad B, Rahman M, Ali A, Islam A. Significance of the electromyographic analysis of the upper limb muscles of cricket bowlers: recommendations from studies of overhead-throwing athletes. Journal of Mechanics in Medicine and Biology. 2014;14(4):1430005.

23. Tucker WS, Armstrong CW, Gribble PA, Timmons MK, Yeasting RA. Scapular Muscle Activity in Overhead Athletes With Symptoms of Secondary Shoulder Impingement During Closed Chain Exercises. Arch Phys Med Rehabil. 2010;91(4):550-556.

24. Quarrie KL, Gianotti SM, Hopkins WG, Hume PA. Effect of nationwide injury prevention programme on serious spinal injuries in New Zealand rugby union: ecological study. BMJ. 2007;334(7604):1150.

25. Myklebust G, Skjolberg A, Bahr R. ACL injury incidence in female handball 10 years after the Norwegian $A C L$ prevention study: important lessons learned. Br J Sports Med. 2013;47(8):476-479.

26. Palmerud G, Forsman M, Sporrong H, Herberts P, Kadefors R. Intramuscular pressure of the infra-and supraspinatus muscles in relation to hand load and arm posture. Eur J Appl Physiol. 2000;83(2-3):223-230.

27. Sood D, Nussbaum MA, Hager K. Fatigue during prolonged intermittent overhead work: Reliability of measures and effects of working height. Ergonomics. 2007; 50(4):497-513.

28. Chopp JN, Fisher SL, Dickerson CR. The Impact of work configuration target angle and hang force direction on upper extremity muscle activity during sub-maximal overhead work. Ergonomics. 2010;53(1):83-91. 